Original Research Paper

\title{
Effect of Heat Moisture Treatment Using Different Solvents and Incubation Times on Resistant Starch Formation of Rice Flour
}

\author{
Anuchita Moongngarm, Piyatida Srijinda, \\ Tatdao Paseephol, Supachai Samana and Nipapon Martphutorn \\ Department of Food Technology and Nutrition, \\ Faculty of Technology, Mahasarakham University, Mahasarakham 44150, Thailand
}

Article history

Received: $12-08-2015$

Revised: $17-08-2015$

Accepted: 19-08-2015

Corresponding Author: Anuchita Moongngarm Department of Food Technology and Nutrition, Faculty of Technology, Mahasarakham University, Maha Sarakham 44150,

Thailand

Email: anuchitac@yahoo.co.th

\begin{abstract}
The thermal and pasting properties and Resistant Starch (RS) formation of high amylose rice flour were investigated at $121^{\circ} \mathrm{C}$ using different solvents and storage times. The samples treated with water and lactic acid $10 \mathrm{mmol} / \mathrm{L}$ with storage times $0,24,48$ and $72 \mathrm{~h}$ had the highest degree of gelatinization, ranging from 98.64 to $99.86 \%$. The samples treated with ethanol and lactic acid $10 \mathrm{mmol} / \mathrm{L}$ (in ethanol) had degrees of gelatinization varying between 58.25 and $59.91 \%$. For the study on the thermal properties, the onset temperature $\left(T_{o}\right)$, peak temperature $\left(T_{p}\right)$, conclusion temperature $\left(\mathrm{T}_{\mathrm{c}}\right)$ and enthalpy $(\Delta \mathrm{H})$ of resistant starch preparation (retrograded rice flour) using water and lactic acid $10 \mathrm{mmol} / \mathrm{L}$ were not observed, but those of heated flour using ethanol and lactic acid in ethanol $(10 \mathrm{mmol} / \mathrm{L})$ were detected. The endothermic peaks of the amyloselipid complex and resistant starch were also observed at higher temperatures from the Differential Scanning Calorimeter (DSC), with no effect of treatments on $T_{0}, T_{p}$ and $T_{c}$. Rice flour heated in water and then stored for $24 \mathrm{~h}$ showed a favorable effect on formation of RS at $10.80 \%$. Significant reductions were observed in all Rapid Visco Analyzer (RVA) viscosities of the retrograded rice flours.
\end{abstract}

Keywords: Resistant Starch, Retrograded Starch, Heat Moisture Treatment, Differential Scanning Calorimeter

\section{Introduction}

Resistant Starch (RS) refers to flour or starch products, which cannot be digested by enzyme $\alpha-1,4$ amylase, or absorbed in the small intestine of humans. This results in health benefits as dietary fibers and prebiotics. When RS passes through the colon it is fermented by bacteria to short chain fatty acids. These acid groups are beneficial to health by inhibiting the growth of pathogenic microorganisms. There are five types of RS named RS1, RS2, RS3, RS4 and RS5 (Englyst et al., 1992; Jane and Robyt, 1984). RS1 is physically entrapped starch, generally found in cereal seeds and legumes. RS2 is condensed and partially crystalline native starch granules found in unripe banana, raw potato and high-amylose corn starches. RS1 and RS2 lose their potential if they are gelatinized during food processing. RS3 consists mainly of retrograded or recrystallized amylose (Garcia-Alonso et al., 1999). RS4 can be produced by the chemical modifications to make the starch resistant to the action of enzymes such as starch phosphates, hydroxypropyl starches, starch acetates and citrate starches (Wepner et al., 1999).

Retrograded resistant starch (RS3) is interesting as it is more stable when the food is processed. It is less complicated and safer than RS4 (chemically modification starch), as it is produced by inducing the starch to physical modification. RS5 is amylose-lipid complex starch, which is resist to amylase hydrolysis. It has a high dissociation temperature and restricts starch granule swelling as a result in high stability when foods are processed (Jane and Robyt, 1984). Generally, RS3 is prepared by gelatinization and retrogradation, the polymerization of starch from gelatinized starch. The crystalline solid obtained from the starch retrogradation is more resistant to enzyme digestion. Starch retrogradation mainly consists of short time retrogradation of amylose and long term retrogradation of amylopectin (Haralampu, 2000). A number of factors affect the retrograded RS formation, including the amylose content and chain length of molecules, gelatinization temperature, storage (retrogradation) time 
and the temperature of the starch gels (Escarpa et al., 1996). Several methods have been used to increase RS yield. The most commonly applied was the acid hydrolysis of amylomaize starch (Chung et al., 2003; Lee et al., 1997; Man et al., 2012; Ozturk et al., 2011; Sodhi et al., 2013; Vasanthan and Bhatty, 1998). Previous studies regarding the induction of RS3 were mainly done on starch from a variety of cereals and root crops. Lin et al. (2011) heated acid and ethanol to produce RS3 in corn starch and Onyango et al. (2006) applied lactic acid and heat moisture treatment to cassava starch. Only few studies have investigated the production of RS3 by heat moisture treatment on rice flour. This study aimed to examine RS formation from rice flour by applying heat moisture treatment and incubation storing using different solvents including water, ethanol and acid hydrolyzing (lactic acid), which these actions might affect several properties of the flour.

\section{Materials and Methods}

\section{Sample Preparation}

Broken rice (Oryza sativa, cultivar Lueng 11) was obtained from Kalasin Province, Thailand. The rice was ground into powder using a hammer mill and passed through a sieve (100 $\mathrm{mm}$ mesh size) to obtain rice flour. The flour was packed in sealed plastic and stored at $4{ }^{\circ} \mathrm{C}$ until required for use. The amylose content of the raw flour was determined $(27.86 \%)$ using the method developed by (Juliano, 1971).

\section{Preparation of Retrograded Rice Flour}

Rice flour slurry was prepared in excess water or solvent (rice flour: Solvent; 1:4). The solvents included water, ethanol (95\%), $10 \mathrm{mmol} / \mathrm{L}$ lactic acid and lactic acid $(10 \mathrm{mmol} / \mathrm{L})$ in $95 \%$ ethanol. The flour suspension was heated in an autoclave at $121^{\circ} \mathrm{C}$ for $1 \mathrm{~h}$ (Onyango et al., 2006). After heating, the heated flour samples were cooled down to $60^{\circ} \mathrm{C}$ and incubated at $60^{\circ} \mathrm{C}$ for four different time periods $(0,24,48$ and $72 \mathrm{~h})$. The treated samples were then tray-dried at $40 \pm 2^{\circ} \mathrm{C}$ until the moisture content of flour reached $10 \%$. The samples were ground and stored at $4{ }^{\circ} \mathrm{C}$ in sealed plastic containers until required for use.

\section{Degree of Gelatinization Determination}

Degree of gelatinization was measured using the differential alkaline solubility method (Birch and Priestley, 1973).

\section{Thermal Property Determination}

The thermal properties of the treated flour samples were determined using a Differential Scanning Calorimeter (DSC, Diamond, Perkin-Elmer, Norwalk, CT). Each sample (1.0 mg, dry basis) was weighed into a stainless steel DSC pan and then deionized water $(3 \mathrm{mg})$ was added. The samples were heated from 30 to $200^{\circ} \mathrm{C}$ at a rate of $10^{\circ} \mathrm{C} / \mathrm{min}$. A differential scanning calorimetry analyzer was calibrated using indium as a standard and an empty DSC pan served as the reference. The onset temperature $\left(T_{0}\right)$, peak temperature $\left(T_{p}\right)$, conclusion temperature $\left(T_{c}\right)$ and enthalpy $(\Delta H)$ were calculated automatically.

\section{Pasting Properties Determination}

The pasting properties of treated rice flour were measured using a Rapid Visco Analyzer (RVA-4, Newport Scientific, Sydney, Australia), adopting the method of Anjum et al. (2007).

\section{Determination of Resistant Starch (RS)}

The RS was measured using a Megazyme resistant starch assay kit (AOAC, 2000) (Megazyme International Ireland Ltd, Bray, Ireland).

\section{Statistical Analysis}

The results of individual samples were reported as the mean \pm SD. Data was analyzed by variance (ANOVA) and Duncan's new Multiple Range Test (MRT), using SPSS statistical software (trial version). The significance differences were set at $95 \%$ confidence level.

\section{Results}

Effect of Heating and Storage on Degree of Gelatinization of Rice Flour

The degree of gelatinization of rice flour obtained from different hydrothermal solutions and stored at $60^{\circ} \mathrm{C}$ for $0,24,48$ and $72 \mathrm{~h}$ is shown in Fig. 1. The rice flour treated with water and lactic acid $10 \mathrm{mmol} / \mathrm{L}$ as solvents showed degrees of gelatinization between 98.64 and $99.69 \%$, whereas the degrees of gelatinization of flour treated with ethanol and lactic acid $(10 \mathrm{mmol} / \mathrm{L}$ in ethanol) were between 58.24 and $60.72 \%$. These findings were similar to Beleia et al. (2006).

\section{Effect of Heat Moisture Treatment and Storage Time on Resistant Starch Content in Rice Flour}

The heat moisture RS preparation samples were stored for different time periods to induce the formation of RS through recrystallization and gelatinization. This process is known as retrogradation. The gelatinized starch is changed from an amorphous to a crystalline state (Miao et al., 2009). Table 1 indicates the effect of the storage time $(0,24,48$ and $72 \mathrm{~h})$ on the formation of RS. The results revealed that the amount of RS significantly reduced with storage time increase from 24 $\mathrm{h}$ for water and 48 to $72 \mathrm{~h}$ at $60^{\circ} \mathrm{C}$ in other treatments. Heat moisture treatment using water and stored at $60^{\circ} \mathrm{C}$ for $24 \mathrm{~h}$ yielded a maximum of $10.80 \%$ of RS. For lactic acid $10 \mathrm{mmol} / \mathrm{L}$, the maximum RS content was $9.47 \%$ after $48 \mathrm{~h}$ and reduced after $72 \mathrm{~h}$. 


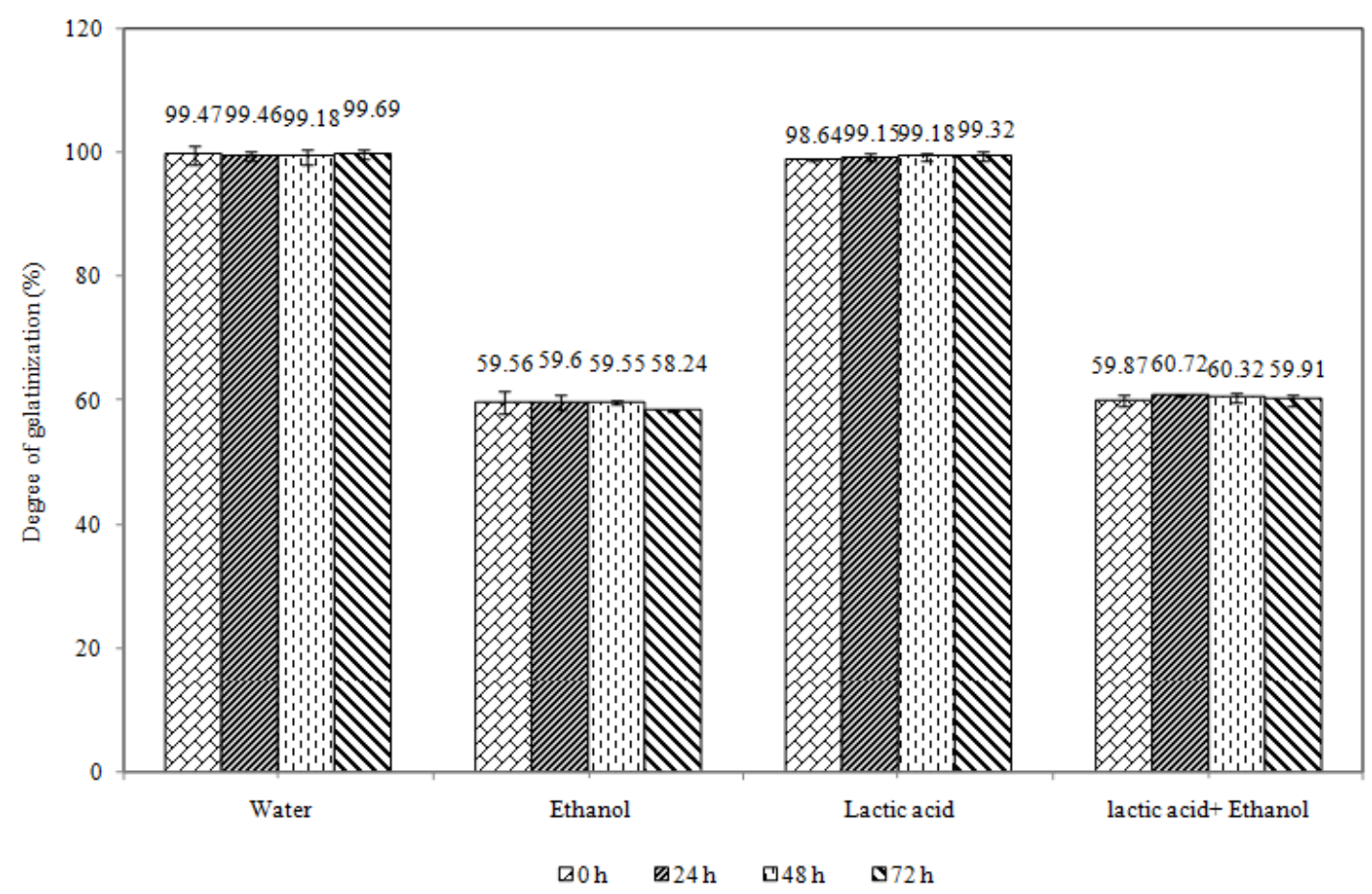

Fig. 1. Effect of heat moisture treatment and storage time on the degree of gelatinization of rice flour

Table 1. Resistant starch content of retrograded flour prepared from heat moisture treatment in different solvents and incubation times

\section{Treatment}

\begin{tabular}{lcl} 
Solution & Incubation Time $(\mathrm{h})$ & RS (\%) \\
\hline Native starch & - & $2.07 \pm 0.29^{\mathrm{k}}$ \\
Water & 0 & $8.49 \pm 0.13^{\mathrm{d}}$ \\
& 24 & $10.80 \pm 0.08^{\mathrm{a}}$ \\
& 48 & $9.14 \pm 0.17^{\mathrm{c}}$ \\
95\% Ethanol & 72 & $5.41 \pm 0.11^{\mathrm{f}}$ \\
& 0 & $4.50 \pm 0.35^{\mathrm{g}}$ \\
& 24 & $1.86 \pm 0.02^{\mathrm{m}}$ \\
& 48 & $1.11 \pm 0.01^{\mathrm{n}}$ \\
Lactic acid & 72 & $3.03 \pm 0.05^{\mathrm{j}}$ \\
(10 mmol/L) & 0 & $4.16 \pm 0.01^{\mathrm{h}}$ \\
& 24 & $8.46 \pm 0.04^{\mathrm{d}}$ \\
Lactic acid & 48 & $9.47 \pm 0.02^{\mathrm{b}}$ \\
(10 mmol/L) & 72 & $6.68 \pm 0.01^{\mathrm{e}}$ \\
in 95\% Ethanol & 0 & $1.33 \pm 0.05^{1}$ \\
& 24 & $4.15 \pm 0.06^{\mathrm{h}}$ \\
& 48 & $5.45 \pm 0.01^{\mathrm{f}}$ \\
Values are & 72 & $3.37 \pm 0.16^{\mathrm{i}}$ \\
\hline
\end{tabular}

Values are means \pm SD of triplicate samples $(n=3)$; values with the same alphabet are not significantly different $(p<0.05)$

The results suggested that longer storage time $\left(60^{\circ} \mathrm{C}\right)$ had a negative effect on RS formation for all treatments. The most suitable storage time was 24 to 48 $\mathrm{h}$, except $95 \%$ ethanol, The results were in accord with Onyango et al. (2006) who studied cassava starch.
Thermal Properties of Resistant Starch (RS) Preparations

The gelatinization properties and endothermic properties of RS preparations (retrograded rice flour) are indicated in Table 2 and 3. The RS preparations showed three endothermic peaks corresponding to gelatinization temperature, amylose-lipid complex (data not shown) and RS. The results revealed that DSC could not detect the gelatinization temperature, $T_{0}, T_{p}, T_{c}$ and $\Delta H$ of the rice flour heated using water and lactic acid $(10 \mathrm{mmol} / \mathrm{L})$. Only the $T_{0}, T_{p}, T_{c}$ and $\Delta H$ of rice flour samples dissolved in ethanol and lactic acid in ethanol $(10 \mathrm{mmol} / \mathrm{L})$ were observed. The RS preparation with different solvents and incubation times differed significantly from the native flour ( $p<(0.05$. Native flour exhibited an initial peak and end gelatinization temperatures at $68.49,73.48$ and $78.24^{\circ} \mathrm{C}$, with an endothermic enthalpy of $1.16 \mathrm{~J} / \mathrm{g}$ dry flour. The $T_{o}$ of treated flour samples (ethanol and lactic acid in ethanol) did not differ from native flour. However, $T_{p}$ and $T_{c}$ were shifted to a higher temperature, with a broader gelatinization temperature for all incubation times than the native flour, as indicated in Table 2.

The endothermic properties of the retrograded RS are presented in Table 3. $T_{o}, T_{p}$ and $T_{c}$ readings of all samples were not significantly different $(P>0.05) . \mathrm{T}_{0}, \mathrm{~T}_{\mathrm{p}}$ and $\mathrm{T}_{\mathrm{c}}$ varied between $150.40^{\circ} \mathrm{C}$ and $159.15^{\circ} \mathrm{C}$, $154.62^{\circ} \mathrm{C}$ and $166.93 \mathrm{C}$ and $174.13^{\circ} \mathrm{C}$ and $187.68^{\circ} \mathrm{C}$, respectively. The $\Delta \mathrm{H}$ values ranged between 8.78 and $11.53 \mathrm{~J} / \mathrm{g}$. The lowest value of $\Delta \mathrm{H}$ was observed in 
treated flour using Lactic acid $(10 \mathrm{mmol} / \mathrm{L})$ in $95 \%$ Ethanol and incubated for $72 \mathrm{~h}$ whereas the highest values were found in several treated conditions.

The retrograded flour used for this study was prepared by incubating RS in water at $60^{\circ} \mathrm{C}$ for $24 \mathrm{~h}$. The pasting parameters of native rice flour and retrograded flour are shown in Table 4. The peak viscosity, break down, final viscosity and setback of native rice flour in
Rapid Visco Units (RVU) were ,178.37 25.94, 325.31 and 183.24, respectively. Peak time and pasting temperature were $6.16 \mathrm{~min}$ and $79.68^{\circ} \mathrm{C}$. After heat moisture treatment and storage, the peak viscosity, breakdown, final viscosity and setback of retrograded rice flour decreased significantly $(\mathrm{p}<0.05)$. However peak time did not change, while peak temperature increased significantly $(\mathrm{p}<0.05)$.

Table 2. Gelatinization properties of rice flour after heat moisture treatment and incubation at different periods of time at $60^{\circ} \mathrm{C}$

\begin{tabular}{|c|c|c|c|c|c|}
\hline $\begin{array}{l}\text { Solvent } \\
\text { Sols }\end{array}$ & Incubation time $(\mathrm{h})$ & $\mathrm{T}_{\mathrm{o}}\left({ }^{\circ} \mathrm{C}\right)^{\mathrm{NS}}$ & $\mathrm{T}_{\mathrm{p}}\left({ }^{\circ} \mathrm{C}\right)^{\mathrm{NS}}$ & $\mathrm{T}_{\mathrm{c}}\left({ }^{\circ} \mathrm{C}\right)$ & $\Delta \mathrm{H}(\mathrm{J} / \mathrm{g} \text { dry flour })^{\mathrm{NS}}$ \\
\hline Native rice flour & - & $68.49 \pm 0.40$ & $73.48 \pm 0.00$ & $78.24 \pm 2.77^{b}$ & $1.16 \pm 0.20$ \\
\hline \multirow{4}{*}{ Water } & 0 & ND & ND & ND & ND \\
\hline & 24 & ND & ND & ND & ND \\
\hline & 48 & ND & ND & ND & ND \\
\hline & 72 & ND & ND & ND & ND \\
\hline \multirow[t]{4}{*}{ 95\% Ethanol } & 0 & $68.06 \pm 0.28$ & $74.07 \pm 0.23$ & $84.75 \pm 0.92^{\mathrm{a}}$ & $1.57 \pm 0.03$ \\
\hline & 24 & $68.15 \pm 0.38$ & $74.38 \pm 0.00$ & $85.10 \pm 1.45^{\mathrm{a}}$ & $1.41 \pm 0.20$ \\
\hline & 48 & $68.24 \pm 0.38$ & $74.89 \pm 0.28$ & $86.05 \pm 1.11^{\mathrm{a}}$ & $1.66 \pm 0.04$ \\
\hline & 72 & $68.03 \pm 0.39$ & $74.34 \pm 0.25$ & $84.76 \pm 1.35^{\mathrm{a}}$ & $1.55 \pm 0.17$ \\
\hline Lactic acid & 0 & ND & ND & ND & ND \\
\hline \multirow[t]{3}{*}{$(10 \mathrm{mmol} / \mathrm{L})$} & 24 & ND & ND & ND & ND \\
\hline & 48 & ND & ND & ND & ND \\
\hline & 72 & ND & ND & ND & ND \\
\hline Lactic acid & 0 & $68.60 \pm 0.57$ & $74.24 \pm 0.02$ & $82.02 \pm 1.11^{\mathrm{a}}$ & $1.17 \pm 0.31$ \\
\hline$(10 \mathrm{mmol} / \mathrm{L})$ & 24 & $67.69 \pm 0.04$ & $73.77 \pm 0.12$ & $83.25 \pm 1.47^{\mathrm{a}}$ & $1.27 \pm 0.19$ \\
\hline \multirow{2}{*}{ in $95 \%$ Ethanol } & 48 & $68.35 \pm 0.10$ & $74.63 \pm 0.00$ & $83.52 \pm 0.29^{\mathrm{a}}$ & $1.31 \pm 0.07$ \\
\hline & 72 & $68.38 \pm 0.38$ & $74.07 \pm 0.02$ & $83.22 \pm 1.37^{\mathrm{a}}$ & $1.29 \pm 0.08$ \\
\hline
\end{tabular}

Values are means \pm SD of triplicate samples $(\mathrm{n}=3)$, values with the same alphabet in the same columns are not significantly different $(p<0.05), \mathrm{NS}=$ Not significantly different at $p>0.05), \mathrm{ND}=$ Not detected

Table 3. Thermal properties of RS preparation prepared from rice flour treated with different solvents and storage times

\begin{tabular}{lcllll}
\hline Solvent & Storage time $(\mathrm{h})$ & $\mathrm{T}_{\mathrm{o}}\left({ }^{\circ} \mathrm{C} \mathrm{C}\right)$ & $\mathrm{T}_{\mathrm{p}}\left({ }^{\circ} \mathrm{C}\right)^{\mathrm{NS}}$ & $\mathrm{T}_{\mathrm{c}}\left({ }^{\circ} \mathrm{C}\right)^{\mathrm{NS}}$ & $\Delta \mathrm{H}(\mathrm{J} / \mathrm{g})$ \\
\hline Water & 0 & $157.73 \pm 0.30^{\mathrm{ab}}$ & $160.01 \pm 1.14$ & $187.68 \pm 1.91$ & $11.35 \pm 0.14^{\mathrm{a}}$ \\
& 24 & $156.81 \pm 0.21^{\mathrm{abc}}$ & $162.93 \pm 1.23$ & $183.14 \pm 1.12$ & $10.72 \pm 0.23^{\mathrm{ab}}$ \\
& 48 & $158.05 \pm 0.33^{\mathrm{a}}$ & $158.92 \pm 0.74$ & $179.29 \pm 1.12$ & $10.16 \pm 0.74^{\mathrm{abc}}$ \\
$95 \%$ Ethanol & 72 & $158.48 \pm 0.40^{\mathrm{a}}$ & $162.08 \pm 0.37$ & $183.26 \pm 0.04$ & $10.22 \pm 0.37^{\mathrm{b}}$ \\
& 0 & $152.40 \pm 1.17^{\mathrm{abc}}$ & $155.86 \pm 1.64$ & $177.76 \pm 1.32$ & $11.05 \pm 0.64^{\mathrm{ab}}$ \\
& 24 & $154.09 \pm 0.77^{\mathrm{abc}}$ & $166.93 \pm 0.82$ & $186.09 \pm 1.54$ & $10.58 \pm 0.82^{\mathrm{ab}}$ \\
Lactic acid & 48 & $157.95 \pm 0.11^{\mathrm{a}}$ & $159.60 \pm 1.71$ & $177.83 \pm 1.87$ & $11.53 \pm 0.71^{\mathrm{a}}$ \\
$(10 \mathrm{mmol} / \mathrm{L})$ & 22 & $159.15 \pm 0.14^{\mathrm{a}}$ & $165.40 \pm 0.37$ & $183.47 \pm 1.71$ & $10.46 . \pm 0.58^{\mathrm{b}}$ \\
& 24 & $154.33 \pm 0.45^{\mathrm{abc}}$ & $160.17 \pm 1.85$ & $181.73 \pm 0.74$ & $10.00 \pm 0.85^{\mathrm{bc}}$ \\
& 48 & $153.03 \pm 0.86^{\mathrm{abc}}$ & $159.25 \pm 0.73$ & $176.01 \pm 0.20$ & $11.03 \pm 0.73^{\mathrm{ab}}$ \\
Lactic acid & 72 & $153.35 \pm 1.54^{\mathrm{abc}}$ & $155.59 \pm 0.65$ & $175.27 \pm 1.76$ & $9.70 \pm 0.17^{\mathrm{c}}$ \\
(10mmol/L) & 0 & $153.27 \pm 1.53^{\mathrm{abc}}$ & $154.62 \pm 1.81$ & $174.13 \pm 1.81$ & $10.34 \pm 0.28^{\mathrm{b}}$ \\
in 95\% Ethanol & 48 & $155.22 \pm 0.88^{\mathrm{abc}}$ & $156.48 \pm 1.17$ & $175.44 \pm 1.83$ & $9.42 \pm 0.03^{\mathrm{c}}$ \\
& 42 & $157.52 \pm 0.80^{\mathrm{ab}}$ & $159.20 \pm 0.01$ & $178.76 \pm 0.79$ & $11.15 \pm 0.36^{\mathrm{ab}}$ \\
\hline Valo & $156.54 \pm 0.01^{\mathrm{abc}}$ & $157.77 \pm 0.00$ & $176.45 \pm 1.83$ & $11.40 \pm 0.85^{\mathrm{a}}$ \\
& 72 & $156.88 \pm 0.00^{\mathrm{abc}}$ & $165.57 \pm 0.00$ & $184.83 \pm 1.86$ & $8.78 \pm 0.98^{\mathrm{cd}}$ \\
\hline
\end{tabular}

Values are means \pm SD of triplicate samples $(\mathrm{n}=3)$, values with the same alphabet in the same columns are not significantly different $(p<0.05)$, NS: Not significantly different at $p>0.05$

Table 4. Pasting parameters of native and retrograded rice flour

\begin{tabular}{lll}
\hline Pasting viscosity (RVU) & Native rice flour & Retrograded rice flour \\
\hline Peak viscosity & $178.37 \pm 4.04^{\mathrm{a}}$ & $132.04 \pm 10.89^{\mathrm{b}}$ \\
Breakdown & $25.94 \pm 4.27^{\mathrm{a}}$ & $3.16 \pm 1.26^{\mathrm{b}}$ \\
Final viscosity & $325.31 \pm 5.68^{\mathrm{a}}$ & $187.95 \pm 7.29^{\mathrm{b}}$ \\
Setback & $183.24 \pm 2.85^{\mathrm{a}}$ & $59.08 \pm 5.91^{\mathrm{b}}$ \\
Peak time (min) & $6.16 \pm 0.56^{\mathrm{a}}$ & $6.91 \pm 0.16^{\mathrm{a}}$ \\
Pasting temperature $\left({ }^{\circ} \mathrm{C}\right)$ & $79.68 \pm 2.28^{\mathrm{b}}$ & $82.02 \pm 1.75^{\mathrm{a}}$ \\
\hline
\end{tabular}

Values are means \pm SD of triplicate samples $(n=3)$, values with the same alphabet in the same lines are not significantly different $(p<0.05)$ 


\section{Discussion}

None of flour samples suspended in water and lactic acid $(10 \mathrm{mmol} / \mathrm{L}$ exhibited the thermal gelatinization peak of the rice flour, because the starch in the treated flour samples was completely gelatinized during the heating process. These results were similar to the study by Alsaffar (2010) on wheat. The $\Delta H$ of the treated flours were lower than that of native rice flour. This may due to some molecules of starch being gelatinized during the heat moisture process (Hoover and Vasanthan, 1994). As indicated in Fig. 1, gelatinization did not take place in the flour dissolved in ethanol, as the ethanol evaporated during heating which resulted in a low degree of gelatinization. The partially and fully cooked flours were also clearly detected by DSC as indicated in Table 1. The fully cooked flour did not show gelatinization during the DSC run.

After heat moisture treatment, the endothermic peaks of native and treated flour samples were shifted to a higher temperature with a broader gelatinization temperature $\left(T_{p}\right)$. These results were consistent with other studies (Gunaratne and Hoover, 2002; Watcharatewinkula et al., 2009). In addition to the rearrangement of amylose and amylopectin inside the starch granules, as suggested by many researchers (Hoover and Vasanthan, 1994; Khunae et al., 2007; Zavareze et al., 2010), the interactions of starch granules and other flour components during the heat moisture treatment also strengthens the structure of the flours, as denoted by greater differences in enthalpy change before and after the heat moisture treatment of the flour samples. The full and partial gelatinization of starch granules could also be a reason for the markedly reduced viscosity of heat moisture treated flour.

From the results in Table 3, this endothermic region was identified as the retrograded flour or RS region. The flour shows a temperature phase shift higher than native flour (not observed) possibly due to modification by the heat moisture treatment as a result of the increase in the crystallinity of the starch granules and rearrangement of the polymer within the amorphous region, which gave rise to a strong adhesion and heat resistance. Higher energy is therefore needed to melt these structures (Lawal, 2005).

The reduction in viscosity and increase in pasting temperature after heat moisture treatment showed similar results as previous reports on rice and corn (Jiranuntakul et al., 2011), canna (Watcharatewinkula et al., 2009), lentil, potato and yam (Hoover and Vasanthan, 1994) and rice flour (Puncha-arnon and Uttapap, 2013). Lim et al. (1999) and Xie et al. (2008) demonstrated that rice protein was primarily responsible for the differences in the pasting properties between rice flour and rice starch. The significant changes in the pasting profile of heat moisture treated rice flour were lower peak viscosity, breakdown and setback. The rice flour still contains protein and other components, which the protein can be denatured by heat treatment. It was assumed that protein and also other compositions in rice flour would also be modified by heat moisture treatment along with the starch granules and that some interactions might occur between them during heat treatment. Accordingly, these changes would account for the differences in paste and gel properties of heat moisture treated rice starch and rice flour.

\section{Conclusion}

The results showed that the heat moisture treatment of rice flour using water (autoclaving temperature $121^{\circ} \mathrm{C}$ ) and incubation time of $24 \mathrm{~h}$ at $60^{\circ} \mathrm{C}$, showed a favorable effect with RS formation as high as $10.80 \%$. As the storage time increased to $72 \mathrm{~h}$, a significant decrease was observed in RS content. Heat moisture treatment had a significant effect on all RVA parameters of RS preparations compared with native flour. The $T_{0}, T_{p}$ and $T_{c}$ transition temperatures did not show significant difference between native and RS preparations. $\Delta \mathrm{H}$ values of all RS preparations significantly decreased compared with the native flour. This study suggests that retrograded RS is a source of functional flour. However, other flour properties influenced by the treatments should be further explored to obtain suitable properties for specific food products such as water binding, cold viscosity, emulsion stability and water solubility.

\section{Acknowledgement}

The authors wish to thank Mr. Patiwit Loypimai for his suggestion on data analysis. We also would like to thank the reviewer team from the Faculty of Technology, Mahasarakham University for their suggestions and proof reading.

\section{Funding Information}

This study is financially supported by Mahasarakham University, Mahasarakham, Thailand (Fiscal year 2014), grant number 2557A10902132.

\section{Author's Contributions}

All authors of this research article have directly participated in the planning, execution and data analysis and manuscript preparation.

\section{Ethics}

This article is original. There are no directly related manuscripts, published or unpublished, by any authors of 
this study. My Institute's, Mahasarakham University, representative, is fully aware of this submission.

\section{References}

Alsaffar, A.A., 2010. Effect of thermal processing and storage on digestibility of starch in whole wheat grains. J. Cereal Sci., 52: 480-485.

DOI: $10.1016 / \mathrm{j} . j \mathrm{cs} .2010 .08 .002$

Anjum, F.M., I. Pasha, M.A. Bugti and M.S. Butt, 2007. Mineral composition of different rice varieties and their milling fractions. Pak. J. Agri. Sci., 44: 332-336.

AOAC, 2000. Official Methods of Analysis of the AOAC. 17th Edn., Association of Official Analytical Chemists, Arlington, Va., ISBN-10: 0935584242.

Beleia, A., S.S. Butarelo and R.S.F. Silva, 2006. Modeling of starch gelatinization during cooking of cassava (Manihot esculenta Crantz). LWT-Food Sci. Technol., 39: 399-404. DOI: $10.1016 /$ j.lwt.2005.02.021

Birch, G.G. and R.J. Priestley, 1973. Degree of gelatinisation of cooked rice. Die Starke, 25: 98-101. DOI: 10.1002/star.19730250308

Chung, H.J., H.Y. Jeong and S.T. Lim, 2003. Effects of acid hydrolysis and defatting on crystallinity and pasting properties of freeze-thawed high amylose corn starch. Carbohydrate Polymers, 54: 449-455. DOI: 10.1016/j.carbpol.2003.05.001

Englyst, H.N., S.M., Kingman and J.H. Cummings. 1992. Classification and measurement of nutritionally important starch fractions. Eur. J. Clin. Nutrit., 46: S33-50.

Escarpa, A., M.C. Gonzalez, L. Garcia-Diz and F. SauraCalixto, 1996. Resistant starch formation: Standardization of a high-pressure autoclave process. J. Agric. Food Chem., 44: 924-928. DOI: $10.1021 /$ jf950328p

Garcia-Alonso, A., J.E. Antomo, M.C. Nuria, B. Laura and S.C. Fulgencio, 1999. Assessment of some parameters involved in the gelatinization and retrogration of starch. Food Chem., 66: 181-187. DOI: $10.1016 / \mathrm{S} 0308-8146(98) 00261-1$

Gunaratne, A. and R. Hoover, 2002. Effect of heatmoisture treatment on the structure and physicochemical properties of tuber and root starches. Carbohydrate Polymers, 49: 425-437. DOI: $10.1016 / \mathrm{S} 0144-8617(01) 00354-\mathrm{X}$

Haralampu, S.G., 2000. Resistant starch-a review of the physical properties and biological impact of $\mathrm{RS}_{3}$. Carbohydrate Polymers, 41: 285-292. DOI: 10.1016/S0144-8617(99)00147-2

Hoover, R.A. and T. Vasanthan, 1994. Effect of heatmoisture treatment on the structure and physicochemical properties of cereal, legume and tuber starches. Carbohydrate Res., 252: 33-53.

DOI: 10.1016/0008-6215(94)90004-3
Jane, J.L. and J.F. Robyt, 1984. Structure studies of amylose- $\mathrm{V}$ complexes and retrograded amylose by action of alpha amylases and a new method for preparing amylodextrins. Carbohydrate Res., 132: 105-118. DOI: 10.1016/0008-6215(84)85068-5

Jiranuntakul, W., C. Puttanlek, V. Rungsardthong, S. Punchaarnon and D. Uttapap, 2011. Microstructural and physicochemical properties of heat-moisture treated waxy and normal starches. J. Food Eng., 104: 246-258. DOI: 10.1016/j.jfoodeng.2010.12.016

Juliano, B.O., 1971. A simplified assay for milled rice amylose. Cereal Sci. Today, 16: 334-338.

Khunae, P., T. Tran and P. Sirivongpaisal, 2007. Effect of heat-moisture treatment on structural and thermal properties of rice starches differing in amylose content. Starch-Starke, 59: 593-599.

DOI: $10.1002 /$ star. 200700618

Lawal, O.S., 2005. Studies on the hydrothermal modifications of new cocoyam (Xanthosoma sagittifolium) starch. Int. J. Biological Macromolecules, 37: 268-277.

DOI: 10.1016/j.ijbiomac.2005.12.016

Lee, S.K., S.H. Mun and M.S. Shin, 1997. Effect of heating conditions on the resistant starch formation. Korean Agric. Chem. Biotechnol., 40: 220-222.

Lim, S.T., J.H. Lee, D.H. Shin and H.S. Lim, 1999. Comparison of protein extraction solutions for rice starch isolation and effects of residual protein content on starch pasting properties. Starch-Sturke, 51: 410-415. DOI: 10.1002/(SICI)1521379X(199904)51:4<120::AID-STAR120>3.0.CO;2-A

Lin, J.H., H. Singhb, C.Y. Wenb and Y.H. Chang, 2011. Partial-degradation and heat-moisture dual modification on the enzymatic resistance and boilingstable resistant starch content of corn starches. J. Cereal Sci., 54: 83-89. DOI: 10.1016/j.jcs.2011.05.001

Man, J., F. Qin, L. Zhu, Y.C. Shi and M. Gu et al., 2012. Ordered structure and thermal property of acidmodified high-amylose rice starch. Food Chem., 134: 2242-2248. PMID: 23442680

Miao, M., B. Jiang and T. Zhang, 2009. Effect of pullulanase debranching and recrystallization on structure and digestibility of waxy maize starch. Carbohydrate Polymers, 76: 214-221.

DOI: 10.1016/j.carbpol.2008.10.007

Onyango, C., T. Bley, A. Jacob, T. Henle and H. Rohm, 2006. Influence of incubation temperature and time on resistant starch type III formation from autoclaved and acid-hydrolysed cassava starch. Carbohydrate Polymers, 66: 494-499. DOI: $10.1016 /$ j.carbpol.2006.04.002

Ozturk, S., H. Koksel and P.K.W. Ng, 2011. Production of resistant starch from acid-modified amylotype starches with enhanced functional properties. J. Food Eng., 103: 156-164.

DOI: 10.1016/j.jfoodeng.2010.10.011 
Puncha-Arnon, S. and D. Uttapap, 2013. Rice starch vs. rice flour: Differences in their properties when modified by heat-moisture treatment. Carbohydrate Polymers, 91: 85-91.

DOI: 10.1016/j.carbpol.2012.08.006

Sodhi, N.S., Y.H. Chang, S. Midha and K. Kohyama, 2013. Molecular structure and physicochemical properties of acid-methanol-treated chickpea starch. Int. J. Food Properties, 16: 125-138. DOI: $10.1080 / 10942912.2010 .535186$

Vasanthan, T. and R.S. Bhatty, 1998. Enhancement of Resistant Starch (RS3) in amylomaize, barley, field pea and lentil starches. Starch-Sturke, 50: 286-291. DOI: $10.1002 /(\mathrm{SICI}) 1521-$ 379X(199807)50:7<286::AID-STAR286>3.0.CO;2-O

Watcharatewinkula, Y., C. Puttanlekb, V. Rungsardthongc and D. Uttapap, 2009. Pasting properties of a heat-moisture treated canna starch in relation to its structural characteristics. Carbohydrate Polymers, 75: 505-511.

DOI: 10.1016/j.carbpol.2008.08.018
Wepner, B., E. Berghofer, E. Miesenberger and K. Tiefenbacher, 1999. Citrate starch: Application as resistant starch in different food systems. Starch/Sturke, 51: 354-361.

DOI: $10.1002 /(\mathrm{SICI}) 1521-$ 379X(199910)51:10<354::AIDSTAR354>3.0.CO;2-W

Xie, L.H., N. Chen, B.W. Duan, Z.W. Zhu and X.Y. Liao, 2008. Impact of proteins on pasting and cooking properties of waxy and non-waxy rice. J. Cereal Sci., 47: 372-379. DOI: $10.1016 /$ j.jcs.2007.05.018

Zavareze, E.D.R., C.R. Storck, L.A.S. de Castro, M.A. Schirmer and A.R.G. Dias, 2010. Effect of heatmoisture treatment on rice starch of varying amylose content. Food Chem., 121: 358-365.

DOI: 10.1016/j.foodchem.2009.12.036 